\title{
Confirmation of $A C R U$ model results for applications in land use and climate change studies
}

\author{
M. L. Warburton, R. E. Schulze, and G. P. W. Jewitt \\ School of Bioresources Engineering and Environmental Hydrology, University of KwaZulu-Natal, PBAG x01, \\ Scottsville 3209, South Africa \\ Received: 25 June 2010 - Published in Hydrol. Earth Syst. Sci. Discuss.: 15 July 2010 \\ Revised: 15 November 2010 - Accepted: 23 November 2010 - Published: 1 December 2010
}

\begin{abstract}
The hydrological responses of a catchment are sensitive to, and strongly coupled to, land use and climate, and changes thereof. The hydrological responses to the impacts of changing land use and climate will be the result of complex interactions, where the change in one may moderate or exacerbate the effects of the other. Further difficulties in assessing these interactions are that dominant drivers of the hydrological system may vary at different spatial and temporal scales.

To assess these interactions, a process-based hydrological model, sensitive to land use and climate, and changes thereof, needs to be used. For this purpose the daily time step $A C R U$ model was selected. However, to be able to use a hydrological model such as $A C R U$ with confidence its representation of reality must be confirmed by comparing simulated output against observations across a range of climatic conditions. Comparison of simulated against observed streamflow was undertaken in three climatically diverse South African catchments, ranging from the semi-arid, sub-tropical Luvuvhu catchment, to the winter rainfall Upper Breede catchment and the sub-humid Mgeni catchment. Not only do the climates of the catchments differ, but their primary land uses also vary. In the upper areas of the Mgeni catchment commercial plantation forestry is dominant, while in the middle reaches there are significant areas of commercial plantation sugarcane and urban areas, while the lower reaches are dominated by urban areas. The Luvuvhu catchment has a large proportion of subsistence agriculture and informal residential areas. In the Upper Breede catchment in the Western Cape, commercial orchards and vineyards are the primary land uses.
\end{abstract}

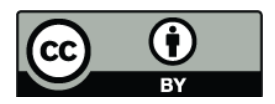

Correspondence to: M. L. Warburton (warburtonm@ukzn.ac.za)
Overall the $A C R U$ model was able to represent the high, low and total flows, with satisfactory Nash-Sutcliffe efficiency indexes obtained for the selected catchments. The study concluded that the $A C R U$ model can be used with confidence to simulate the streamflows of the three selected catchments and was able to represent the hydrological responses from the range of climates and diversity of land uses present within the catchments.

\section{Introduction}

South Africa's land cover and land use have been extensively altered by human activities, such as increasing and shifting populations, increasing and changing food demands, national and regional policies, and other macroeconomic activities. These alterations combine to impact upon the hydrological system at different temporal and spatial scales (Falkenmark et al., 1999; Legesse et al., 2003; Schulze et al., 2004; Calder, 2005).

The hydrological response of a catchment is dependent, inter alia, upon the land use of the catchment, and is sensitive to changes thereof (Schulze, 2000; Bewket and Sterk, 2005), as any changes in land use or land cover alters the partitioning of precipitation between the various pathways of the hydrological cycle (Falkenmark et al., 1999; Costa et al., 2003), such as infiltration, total evaporation $(E)$, surface runoff $\left(Q_{\mathrm{s}}\right)$ or groundwater recharge $\left(Q_{\mathrm{g}}\right)$. Thus, to effectively manage water resources, the interdependence between land use and the hydrological system must be recognized (Comprehensive Assessment of Water Management in Agriculture, 2007) as ultimately, "any land management decision becomes a water management decision" (Falkenmark et al., 1999).

When considering climate change, an additional level of complexity is introduced into the relationship between land

Published by Copernicus Publications on behalf of the European Geosciences Union. 
use and the hydrological system. Together, land use change and climate change form a complex and interactive system, whereby both human influences and climate changes can perturb land use patterns, and changes in land use, in turn, can feed back to influence the climate system (Turner et al., 1995), with both impacting on hydrological responses. Thus, effective water resources management now needs to take account of, and understand, the interactions between land use change, climate change and hydrological responses. It has been suggested that the use of a hydrological model which is conceptualized to accurately represent hydrological processes, sensitive to land use and adequately accounts for climate change drivers provides a means of assessing these complex interactions (Turner et al., 1995; Ewen and Parkin, 1996; Bronstert et al., 2002; Herron et al., 2002; Chang, 2003; Pfister et al., 2004; Hu et al., 2005; Samaniego and Bárdossy, 2006; Lin et al., 2007; Choi and Deal, 2008; Guo et al., 2008; Quilbé et al., 2008).

The ACRU agrohydrological model (Schulze, 1995; Smithers and Schulze, 2004) is one such model that has been suggested to be suitable for such studies as it is a daily time step process-based model with a multi-soil-layer water budget which is sensitive to land management and changes thereof, as well as to climate input and changes thereof (Schulze, 2005). However, to be able to use the ACRU model, and indeed any similar model, with confidence in assessing the interactions between land use change, climate change and hydrological responses, its suitability must be confirmed by assessing its ability to predict output when compared against observed data sets. The objective of this study, therefore, is to confirm the ability of the model through comparisons of its output with observed data sets in three climatically diverse catchments, viz. the Mgeni, Luvuvhu and Upper Breede catchments in South Africa, and thus assess the degree of confidence with which the $A C R U$ model can be used to assess the hydrological responses to land use change and climate change. Using daily data, the study provides an assessment of the model's ability to simulate total and mean flows as well as the variability of these.

For the purposes of this study, the authors have ascribed to the terminology suggested by Oreskes et al. (1994) and Refgaard and Henriksen (2004) that a model's results may be confirmed rather than verified or validated. By confirming the results it produces, the adequacy of the model to produce results of an acceptable level is demonstrated (Refgaard and Henriksen, 2004). Confirmation of model results does not necessarily imply that the model is a truthful representation of reality; rather it supports the probability that the model is a correct representation of reality. The greater the range and number of confirmation studies the greater the probability that the model is not flawed (Oreskes et al., 1994).

The ACRU model has been conceptualized and structured as an operational model to be applied on catchments where streamflow data are not available, and using national databases of climate, soils, and land use as sources of infor- mation, in order to give acceptable results across a range of hydroclimatic regimes. Calibration is a refinement which can be undertaken on catchments with high quality streamflow data, however, few such catchments exist in the developing world or where decisions need to be taken. For these reasons no calibration was undertaken as this would distort the applicability of the model. The purpose of this study was to demonstrate the ability of the $A C R U$ model to simulate under a wide range of climatic regimes and land uses using a robust method of configuration where national level datasets as well as experience-based default parameters were used, with the objective to demonstrate that the model would be suitable to use in extrapolation situations such as climate and land use change impact studies where data beyond the readily obtainable would not be available.

\section{The $A C R U$ agrohydrological model}

The ACRU model is a physical-conceptual, daily time-step, multi-level, multi-purpose model which has been developed over approximately 30 years in the School of Bioresources Engineering and Environmental Hydrology at the University of KwaZulu-Natal in South Africa. The ACRU model has been applied extensively in South Africa for both land use impact studies (e.g. Schulze and George, 1987; Tarboton and Schulze, 1990; Kienzle and Schulze, 1995; Kienzle et al., 1997; Schulze et al., 1997; Jewitt and Schulze, 1999; Schulze, 2000; Jewitt et al., 2004) and climate change impact studies (Perks and Schulze, 1999; Perks, 2001; Schulze et al., 2005). Additionally, the $A C R U$ model has been applied in Zimbabwe (Butterworth et al., 1999; Makoni, 2001), Eritrea (Ghile, 2004), the USA (Martinez et al., 2008), Germany (Herpertz, 1994; Herpertz, 2001) and more recently in New Zealand (Kienzle and Schmidt, 2008; Schmidt et al., 2009) and Canada (Forbes et al., 2010). Figure 1 illustrates the conceptualization of the water budget in the ACRU model. The conceptualizations of the land use processes within the $A C R U$ model are crucial to this study and are described in some detail below.

The ACRU model considers three processes when modelling the land use component, viz. canopy interception loss, evaporation from vegetated surfaces and soil water extraction by plant roots (Schulze, 1995). According to Schulze (1995), $A C R U$ has several options for estimating the canopy interception component. In this study canopy interception losses per rainday were set using the interception loss parameter (ACRU variable name VEGINT) for each month of the year for each land use considered. These values (Table 1), taken from Schulze (2004), range from $3.5 \mathrm{~mm}$ per rainday for mature trees grown for commercial timber production to zero for freshly ploughed land, and they account for intra-annual differences in interception loss with growth stage and dormancy. Intercepted water stored in forest canopies has been found to evaporate at faster rates than the available energy 
Table 1. Monthly values of water use coefficients, canopy interception per rainday, root mass distribution in the topsoil, coefficient of initial abstractions and index of suppression of soil water evaporation by a litter/mulch layer, for the land uses occurring in the Mgeni, Luvuvhu and Upper Breede catchment (Schulze, 2004).

\begin{tabular}{|c|c|c|c|c|c|c|c|c|c|c|c|c|c|}
\hline \multirow[b]{2}{*}{ Land Use } & \multirow[b]{2}{*}{ Variable } & \multicolumn{12}{|c|}{ Monthly values } \\
\hline & & Jan & Feb & Mar & Apr & May & Jun & Jul & Aug & Sep & Oct & Nov & Dec \\
\hline \multicolumn{14}{|l|}{ Commercial Forestry } \\
\hline \multirow[t]{4}{*}{-Acacia } & CAY & 0.90 & 0.90 & 0.90 & 0.88 & 0.85 & 0.86 & 0.89 & 0.90 & 0.92 & 0.92 & 0.90 & 0.90 \\
\hline & VEGINT & 2.00 & 2.00 & 2.00 & 2.00 & 1.90 & 1.85 & 1.85 & 1.85 & 1.90 & 1.95 & 2.00 & 2.00 \\
\hline & ROOTA & 0.83 & 0.83 & 0.83 & 0.83 & 0.83 & 0.83 & 0.83 & 0.83 & 0.83 & 0.83 & 0.83 & 0.83 \\
\hline & COAIM & 0.25 & 0.25 & 0.25 & 0.30 & 0.30 & 0.30 & 0.30 & 0.30 & 0.30 & 0.30 & 0.25 & 0.25 \\
\hline \multirow[t]{4}{*}{-Eucalyptus } & CAY & 0.95 & 0.95 & 0.95 & 0.95 & 0.95 & 0.95 & 0.95 & 0.95 & 0.95 & 0.95 & 0.95 & 0.95 \\
\hline & VEGINT & 2.50 & 2.50 & 2.50 & 2.50 & 2.50 & 2.50 & 2.50 & 2.50 & 2.50 & 2.50 & 2.50 & 2.50 \\
\hline & ROOTA & 0.65 & 0.65 & 0.65 & 0.65 & 0.65 & 0.65 & 0.65 & 0.65 & 0.65 & 0.65 & 0.65 & 0.65 \\
\hline & COAIM & 0.35 & 0.35 & 0.35 & 0.35 & 0.35 & 0.35 & 0.35 & 0.35 & 0.35 & 0.35 & 0.35 & 0.35 \\
\hline \multirow{4}{*}{-Pinus } & CAY & 0.85 & 0.85 & 0.85 & 0.85 & 0.85 & 0.85 & 0.85 & 0.85 & 0.85 & 0.85 & 0.85 & 0.85 \\
\hline & VEGINT & 3.50 & 3.50 & 3.50 & 3.50 & 3.50 & 3.50 & 3.50 & 3.50 & 3.50 & 3.50 & 3.50 & 3.50 \\
\hline & ROOTA & 0.66 & 0.66 & 0.66 & 0.66 & 0.66 & 0.66 & 0.66 & 0.66 & 0.66 & 0.66 & 0.66 & 0.66 \\
\hline & COAIM & 0.35 & 0.35 & 0.35 & 0.35 & 0.35 & 0.35 & 0.35 & 0.35 & 0.35 & 0.35 & 0.35 & 0.35 \\
\hline \multicolumn{14}{|l|}{ Agriculture } \\
\hline & CAY & 0.99 & 0.84 & 0.30 & 0.30 & 0.30 & 0.30 & 0.30 & 0.30 & 0.30 & 0.30 & 0.48 & 0.78 \\
\hline commercial agriculture & VEGINT & 1.40 & 1.40 & 1.40 & 1.20 & 1.00 & 1.00 & 1.00 & 0.80 & 0.00 & 0.00 & 0.80 & 1.40 \\
\hline & ROOTA & 0.78 & 0.91 & 1.00 & 1.00 & 1.00 & 1.00 & 1.00 & 1.00 & 1.00 & 0.92 & 0.79 & 0.74 \\
\hline & COAIM & 0.20 & 0.20 & 0.25 & 0.30 & 0.30 & 0.30 & 0.30 & 0.30 & 0.30 & 0.35 & 0.30 & 0.25 \\
\hline -Irrigated temporary & CAY & 0.7 & 0.7 & 0.7 & 0.7 & 0.7 & 0.7 & 0.7 & 0.7 & 0.7 & 0.7 & 0.7 & 0.7 \\
\hline commercial agriculture & VEGINT & 1.40 & 1.40 & 1.40 & 1.20 & 1.00 & 1.00 & 1.00 & 0.80 & 0.00 & 0.00 & 0.80 & 1.40 \\
\hline & ROOTA & 0.78 & 0.91 & 1.00 & 1.00 & 1.00 & 1.00 & 1.00 & 1.00 & 1.00 & 0.92 & 0.79 & 0.74 \\
\hline & COAIM & 0.20 & 0.20 & 0.25 & 0.30 & 0.30 & 0.30 & 0.30 & 0.30 & 0.30 & 0.35 & 0.30 & 0.25 \\
\hline -Irrigated temporary & CAY & 0.80 & 0.80 & 0.8 & 0.70 & 0.60 & 0.50 & 0.50 & 0.50 & 0.60 & 0.70 & 0.80 & 0.80 \\
\hline commercial agriculture & VEGINT & 1.40 & 1.40 & 1.40 & 1.40 & 1.20 & 1.00 & 1.00 & 1.20 & 1.30 & 1.40 & 1.40 & 1.40 \\
\hline & ROOTA & 0.80 & 0.80 & 0.80 & 0.90 & 1.00 & 1.00 & 1.00 & 1.00 & 0.90 & 0.90 & 0.80 & 0.80 \\
\hline & COAIM & 0.30 & 0.30 & 0.30 & 0.30 & 0.30 & 0.30 & 0.30 & 0.30 & 0.30 & 0.30 & 0.30 & 0.30 \\
\hline -Commercial Sugarcane & CAY (inland) & 0.83 & 0.83 & 0.83 & 0.83 & 0.83 & 0.83 & 0.83 & 0.83 & 0.83 & 0.83 & 0.83 & 0.83 \\
\hline & CAY (coastal) & 0.86 & 0.86 & 0.86 & 0.86 & 0.86 & 0.86 & 0.86 & 0.86 & 0.86 & 0.86 & 0.86 & 0.86 \\
\hline & VEGINT (inland) & 1.70 & 1.70 & 1.70 & 1.70 & 1.70 & 1.70 & 1.70 & 1.70 & 1.70 & 1.70 & 1.70 & 1.70 \\
\hline & VEGINT (coastal) & 1.90 & 1.90 & 1.90 & 1.90 & 1.90 & 1.90 & 1.90 & 1.90 & 1.90 & 1.90 & 1.90 & 1.90 \\
\hline & ROOTA & 0.75 & 0.75 & 0.75 & 0.75 & 0.75 & 0.75 & 0.75 & 0.75 & 0.75 & 0.75 & 0.75 & 0.75 \\
\hline & COAIM & 0.35 & 0.35 & 0.35 & 0.35 & 0.35 & 0.35 & 0.35 & 0.35 & 0.35 & 0.35 & 0.35 & 0.35 \\
\hline -Pasture grass & CAY & 0.55 & 0.55 & 0.55 & 0.55 & 0.35 & 0.20 & 0.20 & 0.20 & 0.35 & 0.45 & 0.55 & 0.55 \\
\hline & VEGINT & 0.70 & 0.70 & 0.70 & 0.70 & 0.70 & 0.70 & 0.70 & 0.70 & 0.70 & 0.70 & 0.70 & 0.70 \\
\hline & ROOTA & 0.95 & 0.95 & 0.95 & 0.95 & 0.95 & 1.00 & 1.00 & 1.00 & 0.95 & 0.95 & 0.95 & 0.95 \\
\hline & COAIM & 0.15 & 0.15 & 0.15 & 0.25 & 0.30 & 0.30 & 0.30 & 0.30 & 0.30 & 0.30 & 0.20 & 0.15 \\
\hline -Subsistence agriculture & CAY & 0.80 & 0.70 & 0.30 & 0.30 & 0.30 & 0.30 & 0.30 & 0.30 & 0.30 & 0.30 & 0.35 & 0.60 \\
\hline & VEGINT & 1.00 & 1.00 & 0.60 & 0.50 & 0.50 & 0.50 & 0.50 & 0.50 & 0.50 & 0.00 & 0.50 & 0.80 \\
\hline & ROOTA & 0.74 & 0.78 & 0.91 & 1.00 & 1.00 & 1.00 & 1.00 & 1.00 & 1.00 & 1.00 & 0.92 & 0.79 \\
\hline & COAIM & 0.20 & 0.20 & 0.25 & 0.30 & 0.30 & 0.30 & 0.20 & 0.20 & 0.20 & 0.35 & 0.30 & 0.25 \\
\hline Urbanised Areas & & & & & & & & & & & & & \\
\hline -Built-up (CBD, industrial areas) & CAY (inland) & 0.70 & 0.70 & 0.70 & 0.60 & 0.30 & 0.30 & 0.30 & 0.30 & 0.45 & 0.65 & 0.70 & 0.70 \\
\hline & CAY (coastal) & 0.80 & 0.80 & 0.80 & 0.70 & 0.50 & 0.50 & 0.50 & 0.50 & 0.55 & 0.75 & 0.80 & 0.80 \\
\hline & VEGINT (inland) & 1.40 & 1.40 & 1.40 & 1.40 & 1.20 & 1.20 & 1.20 & 1.20 & 1.30 & 1.40 & 1.40 & 1.40 \\
\hline & VEGINT (coastal) & 1.6 & 1.6 & 1.6 & 1.6 & 1.4 & 1.4 & 1.4 & 1.4 & 1.5 & 1.6 & 1.6 & 1.6 \\
\hline & ROOTA & 0.80 & 0.80 & 0.80 & 0.90 & 1.00 & 1.00 & 1.00 & 1.00 & 0.95 & 0.80 & 0.80 & 0.80 \\
\hline & COAIM & 0.15 & 0.15 & 0.20 & 0.25 & 0.30 & 0.30 & 0.30 & 0.30 & 0.30 & 0.25 & 0.20 & 0.15 \\
\hline -Formal Residential & CAY (inland) & 0.80 & 0.80 & 0.70 & 0.60 & 0.40 & 0.40 & 0.40 & 0.40 & 0.60 & 0.70 & 0.80 & 0.80 \\
\hline (Suburbs, flats, includes educational areas) & CAY (coastal) & 0.80 & 0.80 & 0.80 & 0.70 & 0.60 & 0.50 & 0.50 & 0.50 & 0.50 & 0.60 & 0.80 & 0.80 \\
\hline & VEGINT (inland) & 1.40 & 1.40 & 1.30 & 1.20 & 1.10 & 1.00 & 1.00 & 1.00 & 1.00 & 1.30 & 1.40 & 1.40 \\
\hline & VEGINT (coastal) & 1.5 & 1.5 & 1.5 & 1.5 & 1.3 & 1.2 & 1.2 & 1.2 & 1.2 & 1.3 & 1.5 & 1.5 \\
\hline & ROOTA & 0.85 & 0.85 & 0.85 & 0.90 & 0.95 & 0.95 & 0.95 & 0.95 & 0.90 & 0.85 & 0.85 & 0.85 \\
\hline & COAIM & 0.20 & 0.20 & 0.20 & 0.30 & 0.30 & 0.30 & 0.30 & 0.30 & 0.30 & 0.30 & 0.25 & 0.20 \\
\hline -Informal Residential & & & & & & & & & & & & & \\
\hline -Urban \& Rural Informal & CAY & 0.65 & 0.65 & 0.65 & 0.55 & 0.30 & 0.20 & 0.20 & 0.20 & 0.30 & 0.50 & 0.55 & 0.65 \\
\hline (differentiation in impervious areas) & VEGINT & 1.50 & 1.50 & 1.50 & 1.50 & 1.50 & 1.50 & 1.50 & 1.50 & 1.50 & 1.50 & 1.50 & 1.50 \\
\hline & ROOTA & 0.90 & 0.90 & 0.90 & 0.94 & 0.98 & 1.00 & 1.00 & 1.00 & 1.00 & 0.95 & 0.90 & 0.90 \\
\hline & COAIM & 0.15 & 0.15 & 0.15 & 0.20 & 0.30 & 0.30 & 0.30 & 0.30 & 0.30 & 0.30 & 0.20 & 0.15 \\
\hline Degraded Natural Vegetation & CAY & 0.55 & 0.55 & 0.55 & 0.45 & 0.25 & 0.2 & 0.2 & 0.2 & 0.4 & 0.45 & 0.55 & 0.55 \\
\hline & VEGINT & 0.8 & 0.8 & 0.8 & 0.7 & 0.6 & 0.6 & 0.6 & 0.6 & 0.65 & 0.75 & 0.8 & 0.8 \\
\hline & ROOTA & 0.9 & 0.9 & 0.9 & 0.95 & 0.95 & 1 & 1 & 1 & 0.95 & 0.9 & 0.9 & 0.9 \\
\hline & COAIM & 0.1 & 0.1 & 0.1 & 0.15 & 0.15 & 0.2 & 0.2 & 0.2 & 0.2 & 0.15 & 0.1 & 0.1 \\
\hline Alien Vegetation & CAY & 0.90 & 0.90 & 0.90 & 0.90 & 0.90 & 0.90 & 0.90 & 0.90 & 0.90 & 0.90 & 0.90 & 0.90 \\
\hline & VEGINT & 1.70 & 1.70 & 1.70 & 1.70 & 1.70 & 1.70 & 1.70 & 1.70 & 1.70 & 1.70 & 1.70 & 1.70 \\
\hline & ROOTA & 0.70 & 0.70 & 0.70 & 0.70 & 0.70 & 0.70 & 0.70 & 0.70 & 0.70 & 0.70 & 0.70 & 0.70 \\
\hline & COAIM & 0.35 & 0.35 & 0.35 & 0.35 & 0.35 & 0.35 & 0.35 & 0.35 & 0.35 & 0.35 & 0.35 & 0.35 \\
\hline
\end{tabular}




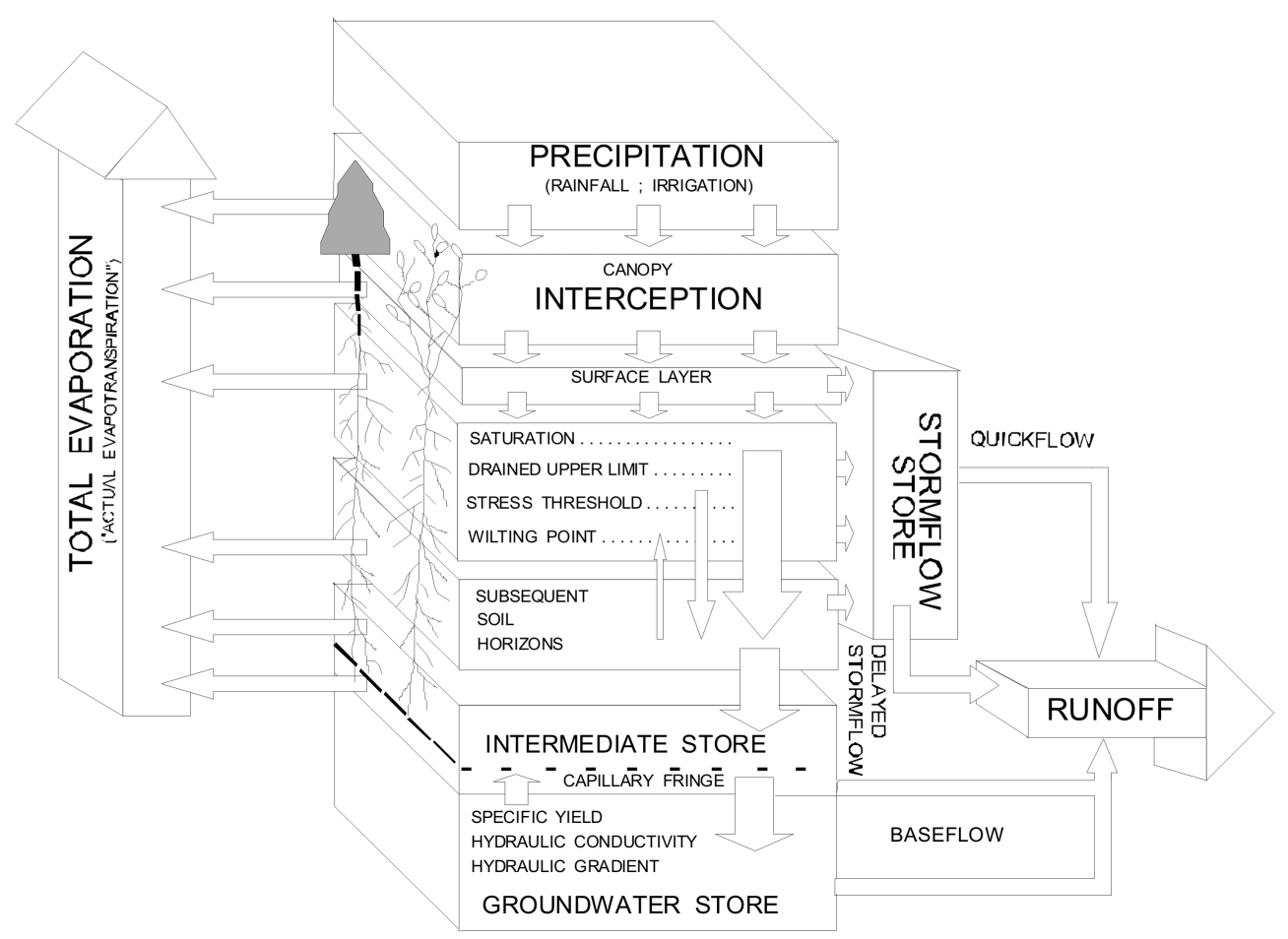

Fig. 1. Representation of the water budget in the ACRU model (Schulze, 1995; Schulze and Smithers, 2004).

from reference potential evaporation because of the higher advection and lower aerodynamic resistances of a wet forest canopy (Calder, 1992). Thus, within $A C R U$ there is an option to enhance evaporation from forest canopies (Schulze, 1995). This option was used for the commercial forestry and alien vegetation land use units of the selected catchments.

Within the ACRU model, total evaporation from a vegetated surface consists of both evaporation of water from the soil surface $\left(E_{\mathrm{S}}\right)$ and transpiration $\left(E_{t}\right)$, which is governed by rooting patterns. These can be modelled either jointly or separately. In this study $E_{\mathrm{s}}$ and $E_{t}$ were modelled separately. The water use coefficient $\left(K_{\mathrm{cm}}\right)$ is used to estimate vegetation water use within the $A C R U$ model. The water use coefficient is expressed as the ratio of maximum evaporation from the plant at a given stage of plant growth to a reference potential evaporation (Schulze, 1995). During periods of sustained plant stress, when the soil water content of both the upper and lower soil horizons falls below $40 \%$ of plant available water, transpiration losses are reduced in proportion to the level of plant stress. When plant available water increases to above $40 \%$ in either soil horizon the plant stress is relieved and the evaporative losses recover to the optimum value at a rate dependent on the ambient temperature (Schulze, 1995). Monthly values of $K_{\mathrm{cm}}$ for each land use are required as input to the model, and from the monthly values, daily values are computed internally in the model using Fourier Analysis (Schulze, 1995). The monthly input parameter values for the land uses considered in this study are given in Table 1.
Extraction of soil water from both soil horizons takes place simultaneously in the ACRU model, and is distributed according to the proportion of active roots within each horizon (Schulze, 1995). Thus, an input requirement is monthly values of the fraction of active roots in the topsoil horizon (ROOTA), from which the fraction in the lower soil horizon is computed internally. These monthly values account for genetic and environmental factors affecting transpiration, for example spring regrowth, winter dormancy, senescence, planting date and growth rates (Schulze, 1995). With regard to soil water extraction under stressed conditions, if the subsoil horizon is not below the stress threshold, but the topsoil horizon is, then the subsoil's contribution to total evaporation will be enhanced beyond that computed for its root mass fraction; similarly, the reverse is true (Schulze, 1995). Evaporation of soil water under wet conditions is suppressed by a surface cover, for example a litter layer (Lumsden et al., 2003). The assumption is made that the relationship between surface cover and soil water evaporation is linear, and that complete surface cover still allows $20 \%$ of maximum evaporation from the soil water to occur. Actual soil water evaporation is calculated by accounting for the wetness of the soil after the suppressed maximum soil water evaporation for a day has been calculated (Lumsden et al., 2003).

The $A C R U$ agrohydrological model is not a model in which parameters are calibrated to produce a good fit; rather, values of input variables are estimated from the physically characteristics of the catchment (Schulze and Smithers, 


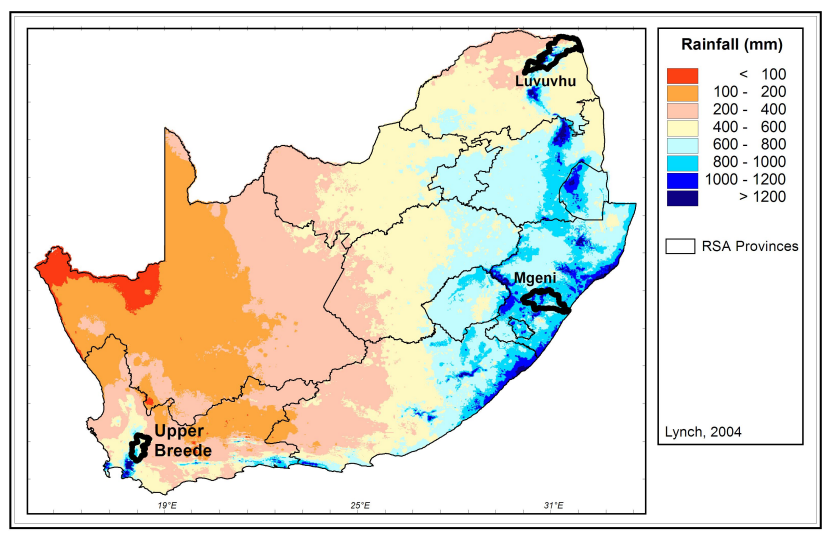

Fig. 2. Location of the study catchments superimposed on a map of the mean annual precipitation (MAP) of South Africa (MAP after Lynch, 2004).

2004) using available information. Thus, a confirmation study to assess the performance of the model in simulating observed data was required, rather than calibration of the model parameters. The catchments which were selected for the confirmation study cover a range of climatic regimes found in South Africa and contain varied land uses. A description of the study areas follows, after which the results of the confirmation study are presented.

\section{The research catchments}

The Mgeni, Luvuvhu and Upper Breede catchments were selected for this study as they vary in both climate and land use. These South African catchments range in climates from the dry sub-tropical regions of the country in the northeast, to the winter rainfall areas of the Western Cape and the wetter eastern seaboard areas of the country with summer rainfall (Fig. 2). The Mgeni catchment is a complex catchment, both in terms of its land use and water engineered system. Although the Mgeni catchment only occupies $0.33 \%$ of South Africa's land surface, it is economically and strategically important as it provides water resources to $\sim 15 \%$ of South Africa's population and supplies the Durban-Pietermaritzburg economic corridor in KwaZuluNatal, which produces ca. $20 \%$ of the country's gross domestic product (Schulze et al., 2004). The Luvuvhu catchment has large areas of subsistence agriculture, but is also important in terms of conservation as it includes parts of the Kruger National Park. The Upper Breede catchment forms part of the headwaters of the Breede River Catchment in the Western Cape, where commercial orchards and vineyards, mostly under irrigation, are the primary activity. A more detailed description of the catchments follows.

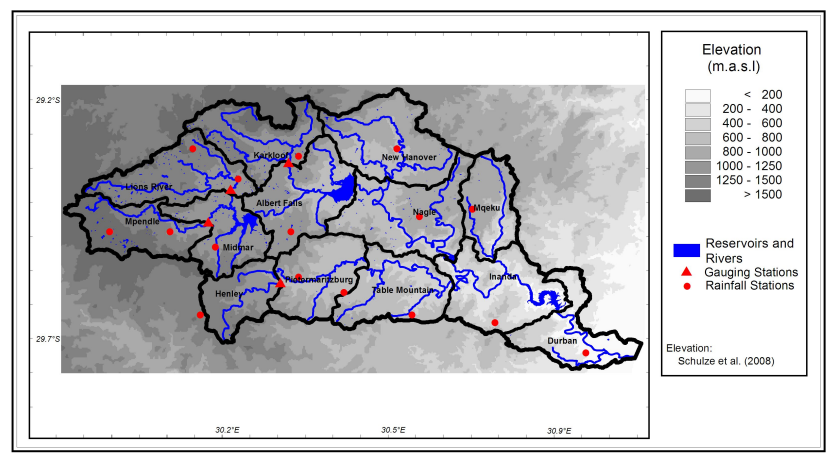

Fig. 3. Water Management Units of the Mgeni catchment.

\subsection{Mgeni catchment}

The Mgeni catchment $\left(4349 \mathrm{~km}^{2}\right)$ is located in the KwaZuluNatal province of South Africa (Fig. 2). The altitude in the catchment ranges from $1913 \mathrm{~m}$ a.s.1 in the western escarpment of the catchment to sea level at the catchment's outlet into the Indian Ocean (Fig. 3). The Mgeni catchment falls within the summer rainfall region of South Africa and generally experiences a warm subtropical climate. The mean annual precipitation (MAP) of the catchment varies from $1550 \mathrm{~mm}$.a in the main water source areas in the west of the catchment to $700 \mathrm{~mm}$ p.a in the drier middle reaches of the catchment. The rainfall throughout the catchment, is however, highly variable, both inter- and intra-annually. The mean annual potential evaporation ranges from $1567 \mathrm{~mm} \mathrm{p.a}$ to $1737 \mathrm{~mm}$ p.a. The mean annual temperature ranges from $12{ }^{\circ} \mathrm{C}$ in the escarpment areas to $20^{\circ} \mathrm{C}$ towards the coastal areas of the catchment.

The water engineered system within the Mgeni currently consists of four main dams (Fig. 3), namely Midmar (full supply capacity of 237 million $\mathrm{m}^{3}$ ) supplying Pietermaritzburg and parts of Durban, as well as Albert Falls $\left(289\right.$ million $\left.\mathrm{m}^{3}\right)$, Nagle $\left(23\right.$ million $\left.\mathrm{m}^{3}\right)$ and Inanda $\left(242\right.$ million $^{3}$ ) dams supplying Durban (Summerton, 2008). Additionally, there are 300 farm dams within the middle to upper reaches of the catchment supplying water for 18500 ha of irrigation. According to Summerton (2008) the Mgeni is a stressed system which is closed to new streamflow reduction activities for the foreseeable future.

The Mgeni catchment consists of 13 water management units (WMUs) as shown in Fig. 3. These WMUs were initially delineated as Quaternary Catchments by the Department of Water Affairs and Forestry according to altitude, topography, soils properties, land cover, water management (water inputs and abstractions), inter-basin transfers, water quality sampling points and streamflow gauging stations and have been used in major studies by Tarboton and Schulze (1992), and later by Kienzle et al. (1997) and Summerton (2008). For the purposes of this study, comparison of model 
Table 2. Summary of selected features and land uses of the Mgeni Catchment and the WMUs selected for the confirmation studies.

\begin{tabular}{lrrrrr}
\hline & $\begin{array}{r}\text { Mgeni } \\
\text { Catchment }\end{array}$ & $\begin{array}{r}\text { Mpendle } \\
\text { WMU }\end{array}$ & $\begin{array}{r}\text { Lions River } \\
\text { WMU }\end{array}$ & $\begin{array}{r}\text { Karkloof } \\
\text { WMU }\end{array}$ & $\begin{array}{r}\text { Henley } \\
\text { WMU }\end{array}$ \\
\hline Area $\left(\mathrm{km}^{2}\right.$ ) & 4349.42 & 295.69 & 362.02 & 334.29 & 219.98 \\
MAP (mm p.a) & 918.18 & 963.48 & 963.72 & 1044.96 & 947.77 \\
Average Altitude (m a.s.l.) & 923.30 & 1556.00 & 1387.29 & 1302.54 & 1280.05 \\
Gauging station & - & U2H013 & U2H007 & U2H006 & U2H011 \\
Land use (\% of area) & & & & & \\
Natural vegetation & 57.1 & 68.2 & 54.4 & 50.3 & 50.9 \\
Water bodies & 1.9 & 1.5 & 1.8 & 0.7 & 0.1 \\
Alien vegetation & 0.7 & 2.7 & 2.0 & 1.0 & 1.7 \\
Degraded areas & 2.4 & 4.1 & 2.1 & 0.5 & 2.7 \\
Commercial forestry & 16.0 & 15.4 & 15.8 & 33.6 & 5.2 \\
Commercial agriculture & & & & & \\
-Sugarcane & 5.8 & 0.0 & 0.0 & 0.0 & 0.0 \\
-Irrigated & 4.4 & 6.2 & 16.5 & 11.1 & 1.8 \\
-Dryland & 1.0 & 1.1 & 7.1 & 2.6 & 0.4 \\
Subsistence agriculture & 2.1 & 0.7 & 0.0 & 0.0 & 12.7 \\
Urban areas & & & & & \\
-Commercial & 0.7 & 0.0 & 0.0 & 0.0 & 0.0 \\
-Formal residential & 2.9 & 0.1 & 0.3 & 0.0 & 0.0 \\
-Informal residential & 4.9 & 0.0 & 0.0 & 0.0 & 24.4 \\
\hline
\end{tabular}

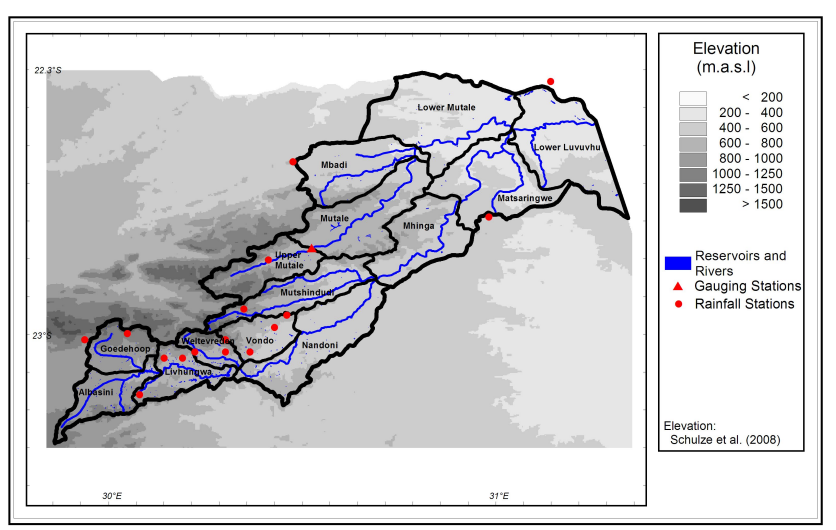

Fig. 4. Luvuvhu Water Management Units.

output against observed data was undertaken at the gauged outlets of the Mpendle, Lions River and Karkloof WMUs and at a gauge point within the Henley WMU (Fig. 3). These WMUs were selected as there are no major dams upstream of the streamflow gauging weirs for which off-takes are not known. The WMUs differ in land use, and observed streamflow data of good quality and reasonable length was available for the time period that corresponds to the available land use data. A summary of the areas, MAPs and land uses in the Mgeni catchment as a whole, as well as the Mpendle, Lions River, Karkloof and Henley WMUs is given in Table 2.

\subsection{Luvuvhu catchment}

The Luvuvhu catchment $\left(5940 \mathrm{~km}^{2}\right)$, situated in the northeast of the Limpopo province of South Africa (Fig. 2), is drained by the Luvuvhu and Mutale Rivers, which flow in an easterly direction up to the confluence with the Limpopo River, on the South Africa and Mozambique border. The climate of the Luvuvhu catchment is variable, both spatially and temporally. The MAP varies from $1870 \mathrm{~mm}$.a in the mountainous regions ( $1360 \mathrm{~m}$ a.s.l.) in the upper reaches of the catchment to $300 \mathrm{~mm}$ p.a in the drier, lower (200 $\mathrm{m}$ a.s.1.) regions of the catchment. The mean annual potential evaporation ranges from $1905 \mathrm{~mm}$ p.a to $2254 \mathrm{~mm}$ p.a. Mean annual temperatures range from $17^{\circ} \mathrm{C}$ in the mountainous regions to $24^{\circ} \mathrm{C}$ towards the catchment outlet. The lower reaches of the Luvuvhu catchment fall within the boundaries of Kruger National Park, an important conservation and ecotourism area. A large proportion of the catchment is under subsistence agriculture (Table 3). The Luvuvhu catchment consists of 14 WMUs (Fig. 4) which were delineated according to the Quaternary Catchments and adjusted to accommodate streamflow gauging stations. Available and good quality observed streamflow data were a constraint for the confirmation study in the Luvuvhu catchment. However, based on a previous study by Jewitt et al. (2004), the Upper Mutale WMU (Fig. 4) presented an ideal opportunity for a confirmation study as high quality streamflow data were available and additionally the land use and climate was representative of the larger Luvuvhu catchment (Table 3). 
Table 3. Summary of selected features and land uses of the Luvuvhu Catchment and the Upper Mutale WMU.

\begin{tabular}{lrr}
\hline & $\begin{array}{r}\text { Luvuvhu } \\
\text { Catchment }\end{array}$ & $\begin{array}{r}\text { Upper Mutale } \\
\text { WMU }\end{array}$ \\
\hline Area $\left(\mathrm{km}^{2}\right)$ & 5940.35 & 328.91 \\
MAP (mm p.a) & 684.49 & 961.02 \\
Average Altitude (m a.s.l.) & 589.45 & 932.92 \\
Gauging Station & - & A9H004 \\
Land use (\% of area) & & \\
Natural vegetation & $62.5 \%$ & $60.8 \%$ \\
Water bodies & $0.2 \%$ & $0.0 \%$ \\
Degraded areas & $8.1 \%$ & $4.3 \%$ \\
Commercial forestry & $6.0 \%$ & $12.7 \%$ \\
Commercial agriculture (Irrigated) & $3.0 \%$ & $2.6 \%$ \\
Subsistence agriculture & $15.8 \%$ & $13.4 \%$ \\
Informal residential areas & $4.4 \%$ & $6.2 \%$ \\
\hline
\end{tabular}

\subsection{Upper breede catchment}

The Upper Breede catchment $\left(2046 \mathrm{~km}^{2}\right)$ is located in the mountainous region of the Western Cape province of South Africa (Fig. 2). The topography of the catchment is fairly rugged, and altitude ranges from of over $1990 \mathrm{~m}$ a.s.l. to $200 \mathrm{~m}$ a.s.l. The Upper Breede catchment falls within the winter rainfall region of South Africa. The rainfall of the catchment is highly variable due to the topography, with the MAP varying between $1190 \mathrm{~mm}$ in the higher areas of the catchment to $350 \mathrm{~mm}$ p.a in the lower areas of the catchment.

Irrigated commercial agriculture is the primary economic activity in the catchment, with the main crop being high value vineyards for wine production. Other farming products include deciduous fruit, dairy and grain. The catchment is also rich in biodiversity, which has led to conflicts between clearing of land for farming and conserving biodiversity (DWAF, 2004). In the lower reaches of the catchment there are two inter-basin transfer schemes which transfer water from the Upper Breede catchment into the neighboring Berg catchment for irrigation purposes (DWAF, 2004). The Upper Breede catchment consists of 11 WMUs, which were delineated according to the Quaternary Catchments, taking into account altitude, topography, land cover and streamflow gauging stations.

For the confirmation study the Koekedou and Upper Breë WMUs were chosen (Fig. 5). These WMUs have good quality observed streamflow data available of reasonable length and the land use of the WMUs is representative of that of the catchment as a whole (Table 4). In addition, these two WMUs are not affected by the interbasin transfer schemes.

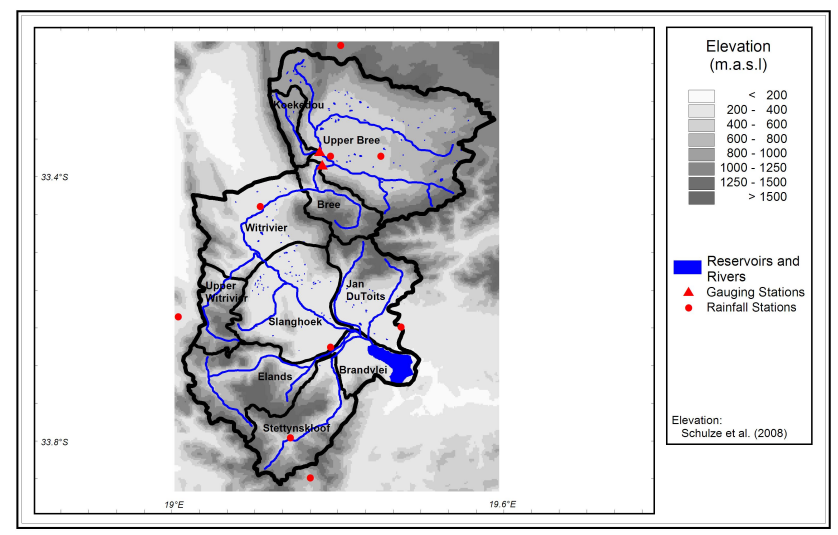

Fig. 5. Upper Breede Water Management Units.

\section{Data sources and model configuration}

\subsection{Subcatchment delineation and configuration}

For each of the study areas, the WMUs were delineated into subcatchments which reflect the altitude, topography, soils properties, land cover, water management (water input and abstractions), and location of gauging stations. Through the delineation process the Mgeni catchment was subdivided into 145 subcatchments, the Luvuvhu catchment into 52 subcatchments and the Upper Breede into 31 subcatchments. These subcatchments can be considered relatively homogeneous in terms of climate and soils; however, the land use within each subcatchment varies. For this reason each subcatchment was further divided into major land use units for modelling purposes. The modelling units were configured such that their streamflows cascade (route) into each other in a logical sequence representative of river flow, and an example of the flow sequence of a subcatchment in the Mgeni is shown in Fig. 6.

\subsection{Historical climatological data}

The hydroclimatological requirements of the $A C R U$ model are daily rainfall and daily reference evaporation (A-pan equivalent), with the latter computed from daily minimum and maximum temperature if not provided explicitly. Representative rainfall stations with daily records were chosen for each of the catchments. For the Mgeni catchment 15 rainfall stations were selected, while 16 rainfall stations were selected for the Luvuvhu catchment and nine to represent the rainfall of the Upper Breede catchment. The stations were chosen on the basis of the reliability of the record, the altitude of the rainfall station in relation to that of the streamflow gauge, and the rainfall station's location in respect of the catchment. For each of the chosen stations a 40-year record (1960-1999) of daily rainfall was extracted from a comprehensive daily rainfall database for South Africa compiled by Lynch (2004). Although every effort was taken by 
Table 4. Summary of selected features and land uses of the Upper Breede Catchment and the WMUs selected for verification.

\begin{tabular}{lrrr}
\hline & $\begin{array}{r}\text { Upper Breede } \\
\text { Catchment }\end{array}$ & $\begin{array}{r}\text { Koekedou } \\
\text { WMU }\end{array}$ & $\begin{array}{r}\text { Upper Breë } \\
\text { WMU }\end{array}$ \\
\hline Area $\left(\mathrm{km}^{2}\right)$ & 2046.44 & 48.17 & 655.74 \\
MAP (mm p.a) & 619.66 & 788.28 & 573.54 \\
Average Altitude (m a.s.1.) & 716.96 & 934.00 & 810.07 \\
Gauging Station & - & $\mathrm{H} 1 \mathrm{H} 013$ & $\mathrm{H} 1 \mathrm{H} 003$ \\
Land use (\% of area) & & & \\
Natural vegetation & $75.8 \%$ & $78.8 \%$ & $66.4 \%$ \\
Water bodies & $2.2 \%$ & $2.5 \%$ & $2.5 \%$ \\
Commercial forestry & $0.5 \%$ & $0.2 \%$ & $0.4 \%$ \\
Commercial agriculture (Irrigated) & & & \\
-Permanent & $12.7 \%$ & $18.5 \%$ & $16.2 \%$ \\
-Temporary & $7.9 \%$ & $0.0 \%$ & $12.9 \%$ \\
Residential \& Urban areas & $0.8 \%$ & $0.0 \%$ & $1.5 \%$ \\
\hline
\end{tabular}

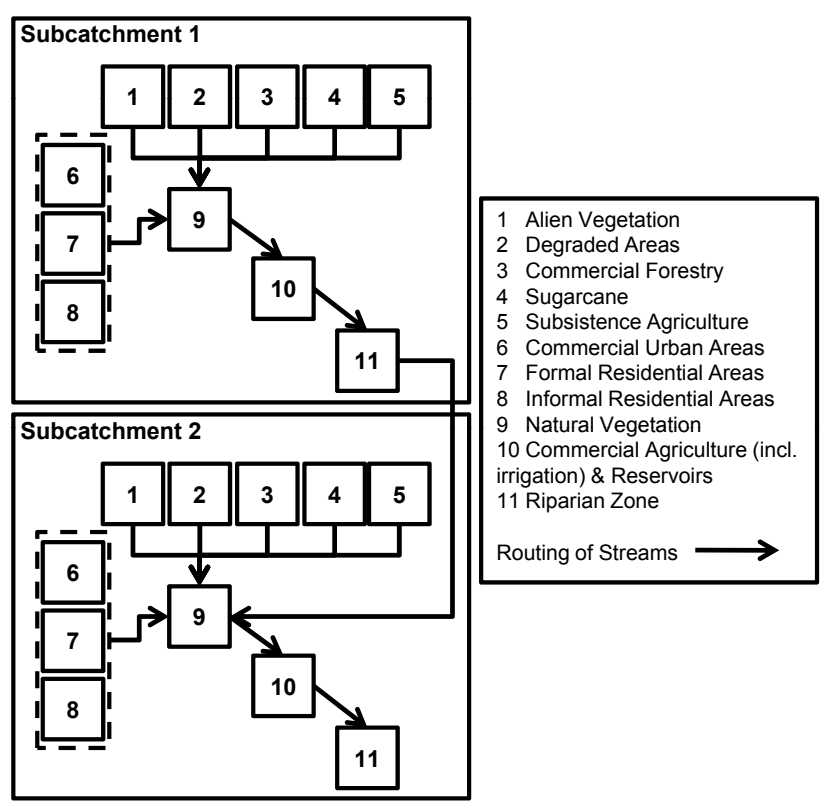

Fig. 6. An example from the Mgeni catchment of cascading (i.e. routing) of flows between subcatchment and land use units within each subcatchment.

Lynch (2004) to remove, or correct for, various identified errors and anomalies, a rainfall database of this magnitude can never be rendered totally error free. To improve the rainfall stations' representation of the catchments' areal rainfall, the option in the ACRU model to adjust the daily rainfall record by a month-by-month adjustment (multiplication) factor was invoked. This monthly adjustment factor was obtained by dividing the catchment's median monthly rainfall obtained from geographically weighted regression derived $1^{\prime}$ by $1^{\prime}$ raster surfaces of median monthly rainfall (Lynch, 2004) by the rainfall station's median monthly rainfall.
As daily A-pan records were not available for the catchment, the Hargreaves and Samani (1985) daily A-pan equivalent reference evaporation equation, which is an option in the $A C R U$ model and only requires daily maximum and minimum temperatures as inputs, was used to estimate daily values. Bezuidenhout (2005) found that the Hargreaves and Samani (1985) equation mimicked the daily values of reference evaporation well for South Africa. The daily minimum and maximum temperatures for the same 40-year period as the rainfall were extracted from a $1^{\prime}$ by $1^{\prime}$ latitude/longitude raster database of daily temperatures for South Africa (Schulze and Maharaj, 2004) for a point closest to the centroid of each subcatchment which represented the median altitude of the subcatchment.

\subsection{Soils}

The ACRU model revolves around a daily multi-layer soil water budget, and operates with surface layer characteristics and two active soil layers, viz. a topsoil and subsoil, into which infiltration of rainfall occurs and in which rooting development and soil water extraction take place through the evaporation and transpiration processes, as well as capillary movement and saturated drainage (Schulze, 1995). Thus, information is required on the thickness of the topsoil and subsoil, as well as on soil water content at the soil's lower limit (i.e. permanent wilting point), its drained upper limit (i.e. field capacity) and saturation for both the topsoil and subsoil, and furthermore also on the fraction of "saturated" soil water (above drained upper limit) to be redistributed daily from the topsoil to the subsoil, and from the subsoil into the intermediate/groundwater store (Schulze, 1995). Values for these variables were obtained for the three study areas from the electronic data accompanying the "South African Atlas of Climatology and Agrohydrology" (Schulze et al., 2008). 
Table 5. Percentages of adjunct and disjunct impervious areas for different urbanized land uses (after Schulze and Tarboton, 1995).

\begin{tabular}{lrr}
\hline Urbanized Land Use & $\begin{array}{r}\text { Adjacent Impervious } \\
\text { Areas (\%) }\end{array}$ & $\begin{array}{r}\text { Disjunct Impervious } \\
\text { Areas (\%) }\end{array}$ \\
\hline Built-up (CBD, Industrial) & 30 & 15 \\
Formal Residential & 20 & 10 \\
Informal Rural Residential Areas & 10 & 5 \\
\hline
\end{tabular}

\subsection{Streamflow response variables}

In the $A C R U$ model, streamflow response variables are used to govern the portion of generated stormflow exiting a catchment on a particular day, as well as the portion of baseflow originating from the groundwater store, which contributes to streamflow. For the Mgeni and Luvuvhu catchments it was assumed that $30 \%$ of the total stormflow generated in a subcatchment would exit the same day as the rainfall event which generated the stormflow, this being a typical value for South African subcatchments of the size in this study (Schulze et al., 2004). However, given the steepness of the Upper Breede catchment it was assumed that $60 \%$ of the total stormflow generated in a subcatchment would exit on the same day (Schulze et al., 2004). On any particular day it is assumed that $0.9 \%$ of the groundwater store will become baseflow. This value has been found to be representative of large parts of southern Africa (Schulze et al., 2004). The thickness of the soil profile from which stormflow generation occurs is set to the thickness of the topsoil, except in the sugarcane and commercial forestry land use units where is was set to 0.35 in accordance with the various studies reviewed in Schulze (1995). The above streamflow response variables have been based largely on experiences in simulations on small and large, research and operational catchments in climatic regimes ranging from semi-arid to sub-humid.

The coefficient of initial abstraction is a variable in $A C R U$ which is used to estimate the rainfall abstracted by soil surface interception, detention surface storage and initial infiltration before stormflow commences (Schulze, 1995). This value varies from month-to-month and differs, inter alia, according to land use, soil surface conditions and typical seasonal rainfall intensity characteristics (Schulze, 2004; Table 1). Impervious areas are hydrologically important and are represented in the urbanized land use units by inputting the fraction of the subcatchment that is impervious according to typical South African values developed by Schulze and Tarboton (1995). In regard to impervious areas the model distinguishes between adjunct impervious areas which are connected directly to rivers or stormwater systems and disjunct impervious areas, i.e. those not connected directly to rivers or stormwater systems, with values used in this study shown in Table 5. The fraction of the subcatchment which is specified as an adjunct impervious area contributes directly to the streamflow at the outlet of the subcatchment under consideration on the same day as the rainfall event occurred. On the other hand, the runoff generated from the fraction of the subcatchment specified as disjunct impervious contributes directly to the soil water budget and runoff responses of the pervious portion of the subcatchment under consideration.

\subsection{Water bodies and irrigation}

Surface areas of the reservoirs in the Mgeni, Luvuvhu and Upper Breede catchments were obtained from 1:50000 topographic map sheets dating from 1996 to 2002. Using the algorithm developed by Tarboton and Schulze (1992) the capacity of the reservoirs was calculated from these surface areas. Reservoir seepage was assumed to be equal to $1 / 1500$ of the dam's capacity. Although environmental flow schedules exist for large dams, no environmental flow estimates were available for farm dams in the headwaters of the catchments thus, as suggested in Schulze (1995), environmental flows were assumed to be equal to seepage.

Irrigation areas were identified from the NLC (2000). The irrigation schedule was set at $20 \mathrm{~mm}$ applied in a fixed 7 day cycle, with the cycle interrupted only after $20 \mathrm{~mm}$ of rain on a given day. Spray evaporation and wind drift losses were input at $12 \%$ and conveyance losses at $10 \%$ following typical values summarized by Smithers and Schulze (2004).

\section{Results of confirmation studies}

The model was run for the full rainfall record, but the period for the confirmation exercises was governed by availability of gauged data for the respective WMUs. Given the objective of the study to be an assessment of the confidence with which the $A C R U$ model can be used when determining hydrological responses to changes in land use and climate, the ability of the model to simulate the variability of streamflows as well as accumulated flows was considered. For this study, the objectives for an adequate simulation were set as a percentage difference between the sum of simulated flows $\left(\sum Q_{\mathrm{s}}\right)$ and sum of observed flows $\left(\sum Q_{\mathrm{o}}\right)$ of less than $15 \%$ of $\sum Q_{\mathrm{o}}$, a percentage difference between the standard deviation of simulated daily flows $\left(\sigma_{\mathrm{s}}\right)$ and standard deviation of observed flows $\left(\sigma_{\mathrm{o}}\right)$ of less than $15 \%$ of $\sigma_{\mathrm{o}}$, and an $R^{2}$ value in excess of 0.7 for daily simulated flows. These objectives 
Table 6. Statistics of performance of the $A C R U$ model Mgeni Catchment: comparison of Daily Observed and Simulated Values.

\begin{tabular}{lrrrr}
\hline WMU (1987-1998) & Mpendle & Lions River & Karkloof & Henley \\
\hline Total observed flows (mm) & 3444.068 & 2507.196 & 3456.985 & 2635.724 \\
Total simulated flows (mm) & 3171.486 & 2257.643 & 3005.969 & 2533.988 \\
Ave. error in flow (mm/day) & -0.063 & -0.058 & -0.105 & -0.024 \\
Mean observed flows (mm/day) & 0.796 & 0.582 & 0.803 & 0.629 \\
Mean simulated flows (mm/day) & 0.733 & 0.524 & 0.698 & 0.605 \\
\% Difference between means & $7.91 \%$ & $9.95 \%$ & $13.05 \%$ & $3.86 \%$ \\
Std. Deviation of observed flows (mm) & 1.823 & 1.734 & 1.228 & 1.246 \\
Std. Deviation of simulated flows (mm) & 2.011 & 1.947 & 1.305 & 1.541 \\
\% Difference between Std. Deviations & $-10.34 \%$ & $-12.31 \%$ & $-6.26 \%$ & $-23.67 \%$ \\
Correlation Coefficient : Pearson's R & 0.915 & 0.939 & 0.844 & 0.886 \\
Regression Coefficient (slope) & 1.009 & 1.055 & 0.897 & 1.095 \\
Regression Intercept & -0.070 & -0.090 & -0.022 & -0.084 \\
Coefficient of Determination: $R^{2}$ & 0.836 & 0.882 & 0.713 & 0.785 \\
Nash-Sutcliffe Efficiency Index $\left(E_{\mathrm{f}}\right)$ & 0.802 & 0.847 & 0.655 & 0.654 \\
\hline
\end{tabular}

are those suggested for daily simulations by Smithers and Schulze (2004) given the high spatial variability of rainfall in the catchments. To evaluate the goodness-of-fit further, the Nash-Sutcliffe efficiency index $\left(E_{\mathrm{f}}\right)$ (Nash and Sutcliffe, $1970)$ was used. Values of $E_{\mathrm{f}}$ that are similar in magnitude to the coefficient of determination indicate a satisfactory simulation, and thus fulfil the objective for this study.

\subsection{Mgeni catchment results}

Statistics of the performance of the $A C R U$ model on the four WMUs included in the confirmation study for the Mgeni catchment are shown in Table 6, graphs of observed and simulated streamflow, with the daily values accumulated to monthly totals, are shown in Fig. 7, and flow duration curves of daily simulated and observed streamflows are shown in Fig. 8. Gauged data were available for 1987-1998. For the Mpendle WMU the low flows and the high flows were marginally undersimulated (Fig. 7 and 8), with the simulated stormflows not being responsive to actual events. The unresponsiveness of the stormflows could be attributed to the portion of degraded land in the WMU, which totals 4\%. However, this degraded land is unevenly distributed through the WMU, making the simulation of its combined effects difficult. As the total flows are adequately simulated, the percentage difference between the observed and simulated standard deviation is less than $15 \%$, the $R^{2}$ of daily values is 0.836 and the Nash-Sutcliffe $E_{\mathrm{f}}$ is 0.802 (Table 6), the simulation of streamflow in the Mpendle WMU can be considered highly acceptable.

The Lions River WMU similarly produced acceptable results with an $R^{2}$ of 0.882 (Table 6). Total values of streamflow were, however, undersimulated, with the rates of baseflow (Fig. 8) and, consequently, the hydrograph recessions providing the reason for the undersimulation (Fig. 7).
Both high flows and low flows were undersimulated in the Karkloof WMU (Figs. 7 and 8), resulting in a difference of $13.05 \%$ between the daily means of the simulated and observed streamflows. However, the simulation was considered reasonable given that the Nash-Sutcliffe $E_{\mathrm{f}}$ is 0.655 and the other statistics (Table 6) fell within the objectives outlined for this confirmation study. The large portion of the Henley WMU under informal residential areas made this WMU a problematic catchment to model. Informal residential areas in South Africa are unstructured and diverse in their nature. In modelling these areas, it is not possible to fully capture the diversity of land uses and soil compaction within these areas. Thus, due to this difficulty the results of the confirmation study for the Henley WMU can be considered reasonable as all statistics, except for the percentage difference between the standard deviations were within the objectives set for the confirmation study, and flow duration curve (Fig. 8) indicates that the variability of streamflow was adequately simulated.

The range of land uses represented in the catchment as a whole, and within the individual WMUs, made it difficult to achieve satisfactory simulations. This difficulty was reflected in the statistics produced by the confirmation study. Overall, however, the ACRU model performed well on each of the four WMUs included in the confirmation study. The above results show that the $A C R U$ model can be used to simulate streamflows of the Mgeni catchment, with its highly diverse land uses, with reasonable confidence.

\subsection{Luvuvhu catchment results}

Observed streamflow data of appropriate quality in the Luvuvhu Catchment were only available for one gauging station, viz. A9H004, which is located at the outlet of the Upper Mutale WMU. The period of acceptable data is 1970 to 1990. The statistics of goodness-of-fit (Table 7) for the 

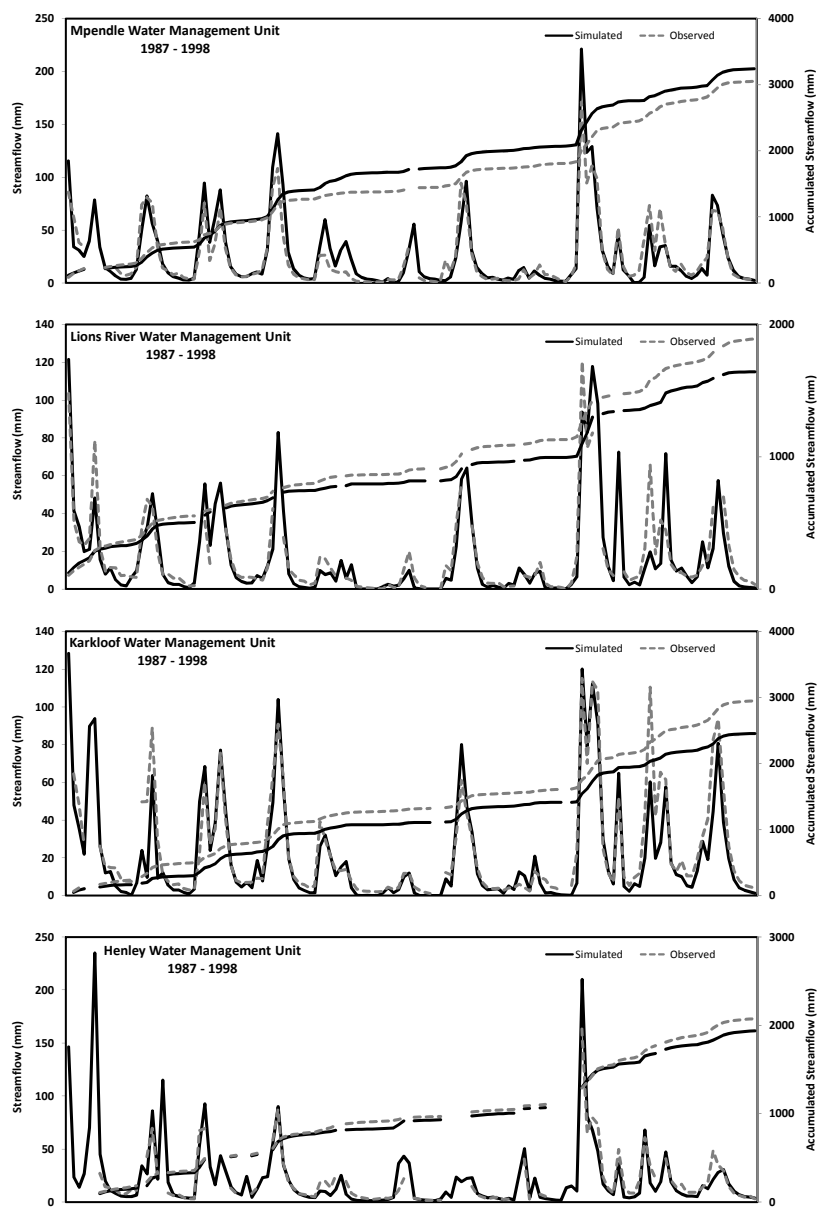

Fig. 7. Comparison of monthly totals of daily simulated and observed streamflows for (from top to bottom) the Mpendle WMU, Lions River WMU, Karkloof WMU and the Henley WMU of the Mgeni Catchment.

Upper Mutale WMU are highly acceptable. Total values of streamflow are simulated well, with accumulated totals of observed and simulated streamflows following similar patterns (Fig. 9). The high flows are slightly undersimulated, the median flows slightly oversimulated and the low flows are well simulated (Fig. 10), this is further indicated by the regression coefficient of 0.859 and intercept of 0.177 . The Nash-Sutcliffe $E_{\mathrm{f}}$ of 0.715 supported the acceptability of the results (Table 7). The satisfactory goodness-of-fit statistics produced for the Upper Mutale WMU imply that it may be suggested that streamflows of the larger Luvuvhu Catchment can also be simulated with confidence using the $A C R U$ model.

\subsection{Upper breede catchment results}

The verification study in the Upper Breede Catchment was carried out on two WMUs for the period 1987-1998 for which observed streamflow data were available. The
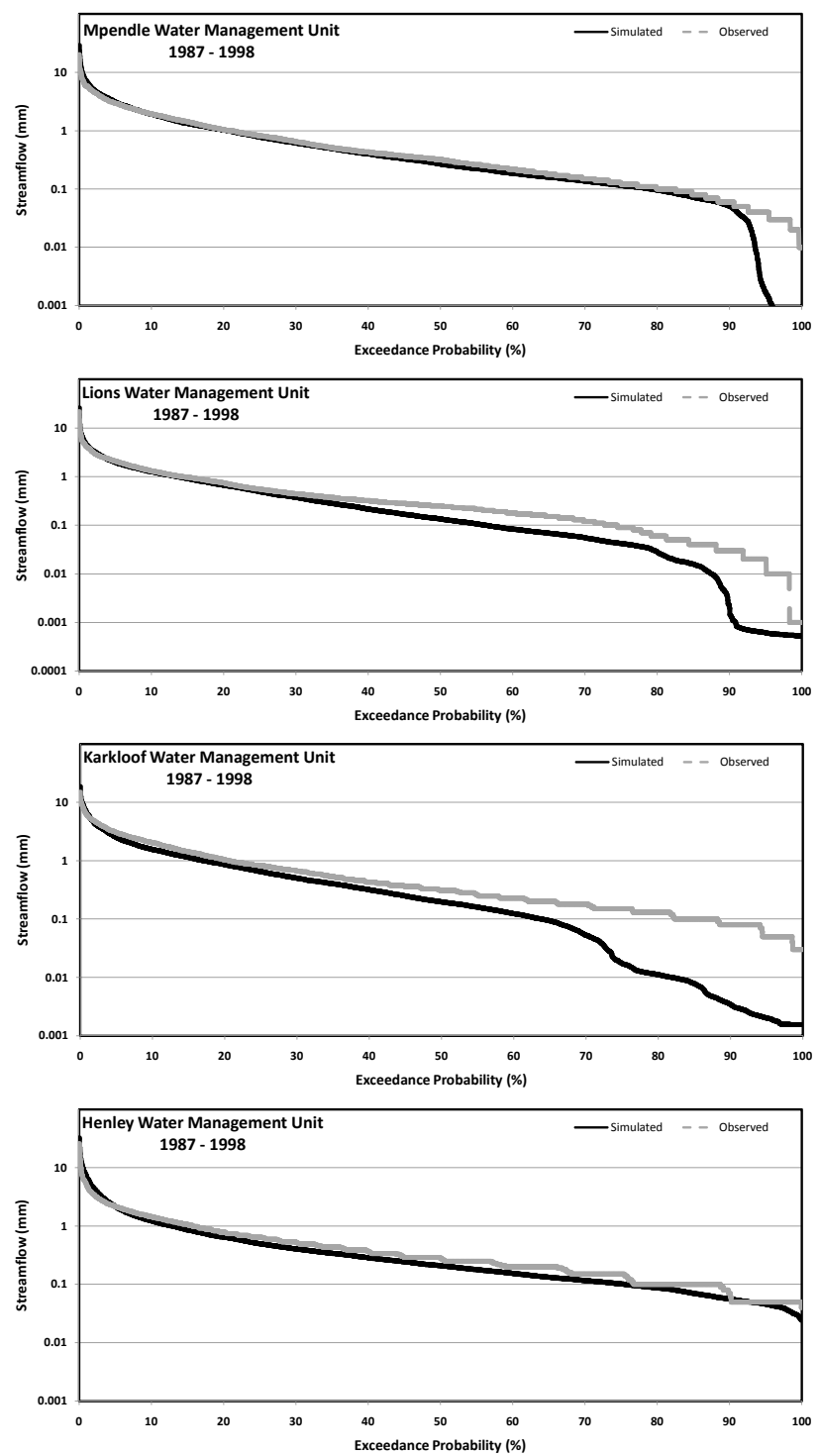

Fig. 8. Comparison of flow duration curves of daily simulated and observed streamflows for (from top to bottom) the Mpendle WMU, Lions River WMU, Karkloof WMU and the Henley WMU of the Mgeni Catchment.

goodness-of-fit statistics produced for the Koekedou WMU are highly acceptable (Table 8 ). The Nash-Sutcliffe $E_{\mathrm{f}}$ of 0.785 was attained. Total accumulated flows (Fig. 11, top) were well simulated, with the simulated pattern closely matching that of the observed. However, the regression intercept, regression coefficient (Table 8) and comparison of flow duration curves of daily observed and simulated streamflows (Fig. 12, top) indicate an oversimulation of the baseflows and a slight undersimulation of the high flows.

The statistics of performance for the Upper Breë show that the $R^{2}$ value of 0.712 , the percentage difference of the means and the percentage difference of the standard 


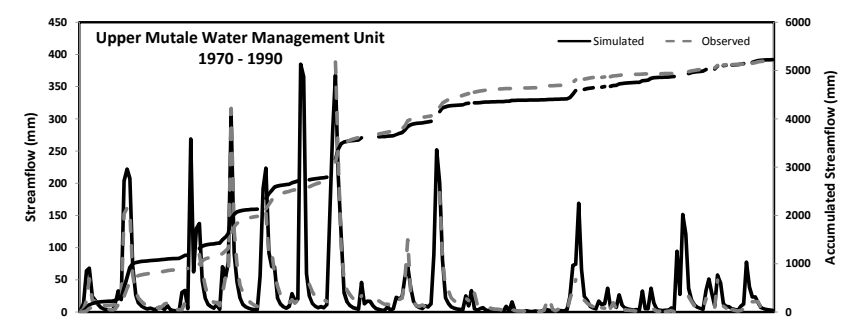

Fig. 9. Comparison of monthly totals of daily simulated and observed streamflows for the Upper Mutale WMU of the Luvuvhu Catchment.

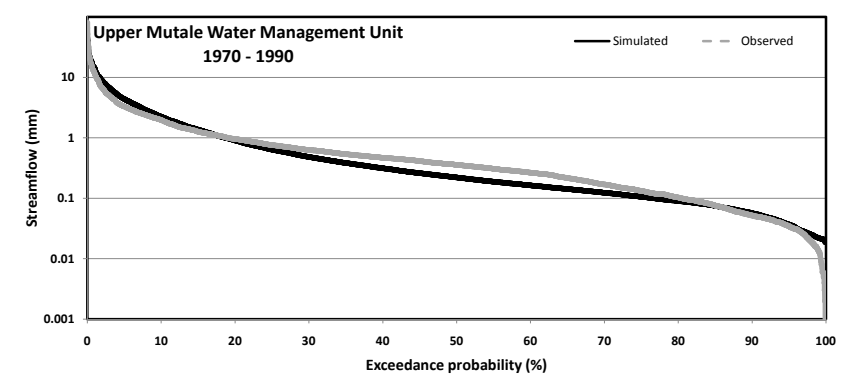

Fig. 10. Comparison of flow duration curves of daily simulated and observed streamflows for the Upper Mutale WMU of the Luvuvhu Catchment.

deviations between simulated and observed flows fall within the acceptable limits outlined for the confirmation study (Table 8). However, the total accumulated flows for the Upper Breë WMU were oversimulated (Fig. 11, bottom), the high flows were undersimulated and the low flows oversimulated (Fig. 12, bottom). One reason for this is that the Upper Breë WMU contains steep topography which makes capturing the responsiveness of high flows difficult. However, since statistics of performance were within the acceptable limits outlined for the study, the simulation for the Upper Bree WMU can be considered acceptable. As the ACRU model performed well on the Koekedou and satisfactorily on the Upper Breë WMU, it is concluded that streamflows for the Upper Breede Catchment can be simulated with reasonable confidence.

\section{Discussion}

No fieldwork was carried out in the Mgeni, Luvuvhu and Upper Breede Catchments to determine values of input variables. Thus the simulation results produced in this confirmation study were based on national land use and soils information, together with default input values obtained from the ACRU User Manual where no better information was available. Based on the simulation results presented above and that the $E_{\mathrm{f}}$ ranged between 0.847 and 0.597 , it is suggested that the ACRU model can be used with confidence
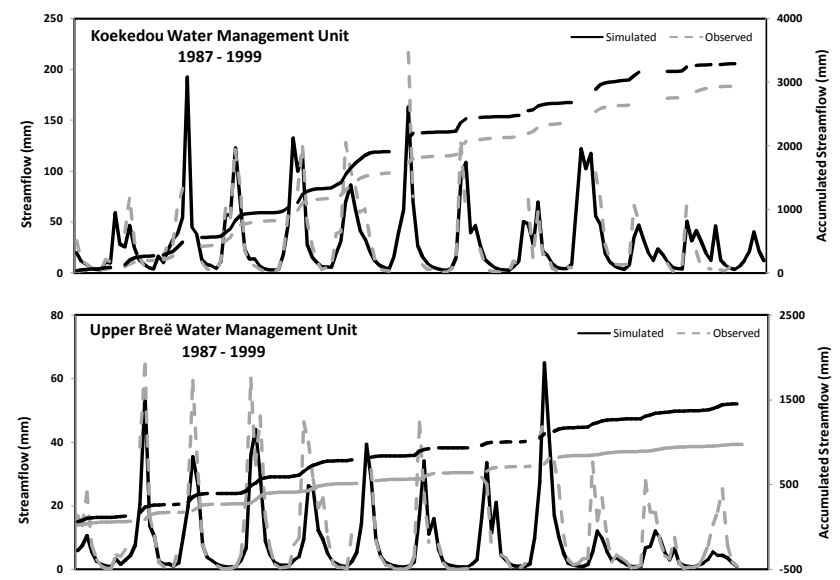

Fig. 11. Comparison of monthly totals of daily simulated and observed streamflows for (from top to bottom) the Koekedou WMU and the Upper Breë WMU of the Upper Breede Catchment.
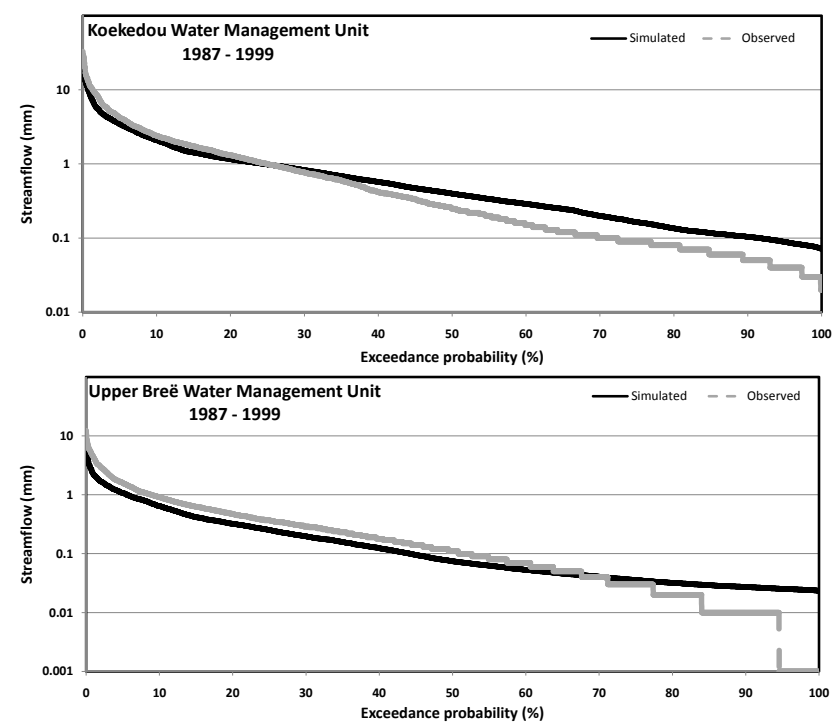

Fig. 12. Comparison of flow duration curves of daily simulated and observed streamflows for (from top to bottom) the Koekedou WMU and the Upper Breë WMU of the Upper Breede Catchment.

to simulate the streamflows of the Mgeni, Luvuvhu and Upper Breede Catchments. The ACRU model has been used to aid decision-making in South Africa, and applied in numerous hydrological designs, water resource assessments and research projects both in South Africa and internationally (Schulze, and George, 1987; Schulze, 1988; Smithers, 1991; Tarboton, and Schulze, 1991; Smithers, and Caldecott, 1993; New and Schulze, 1996; Butterworth et al., 1999; Jewitt and Schulze, 1999; Smithers et al., 2001; Schulze and Smithers, 2004; Jewitt et al., 2004; Kiker et al., 2006). To demonstrate the model's ability and acceptance, confirmation studies, and in particular confirmation studies at a daily time interval, 
Table 7. Statistics of performance of the $A C R U$ model Luvuvhu Catchment: comparison of Daily Observed and Simulated Values.

\begin{tabular}{lr}
\hline WMU (1970-1990) & Upper Mutale \\
\hline Total observed flows (mm) & 6689.166 \\
Total simulated flows (mm) & 7056.196 \\
Ave. error in flow (mm/day) & 0.050 \\
Mean observed flows (mm/day) & 0.904 \\
Mean simulated flows (mm/day) & 0.954 \\
\% Difference between means & $-5.49 \%$ \\
Std. Deviation of observed flows (mm) & 2.631 \\
Std. Deviation of simulated flows (mm) & 2.635 \\
\% Difference between Std. Deviations & $0.16 \%$ \\
Correlation Coefficient: Pearson's R & 0.858 \\
Regression Coefficient (slope) & 0.859 \\
Regression Intercept & 0.177 \\
Coefficient of Determination: $R^{2}$ & 0.736 \\
Nash-Sutcliffe Efficiency Index $\left(E_{\mathrm{f}}\right)$ & 0.715 \\
\hline
\end{tabular}

need to be undertaken. This study, beyond gaining confidence in the ACRU model's ability to be used in assessments of impacts of land use and climate changes on hydrological responses, adds to the available literature confirming that the model's process representation is a relatively accurate reflection of reality at a daily time step and over a range of climatic regions.

Although confidence in the ACRU model's ability to simulate hydrological responses with past and present observational data has been demonstrated under widely ranging climatic and land use conditions, this is no guarantee that the model will necessarily continue to perform at a satisfactory level when used to predict the future (Oreskes et al., 1994). The hydrological system is dynamic (Nordstrom et al., 2005) and, under future climate scenarios, may change in unanticipated ways and may exceed the range under which the model's process representations have been tested. Determination of model input variables such as the streamflow response variables, and the question as to whether the conceptualizations of the processes within the model will be the same under future changes, remain major sources of uncertainty in hydrological modelling. However, to aid future water resource planning, simulations of hydrological responses to plausible scenarios land use and climate change are required. The uncertainties in this regard should be, therefore, recognized and, where possible, be constrained (Beven, 2006), rather than being seen as a reason not to proceed with studies projecting future changes.

By covering a wide range of climates, from the dry subtropical Luvuvhu catchment, to the wetter and sub-humid Mgeni catchment in a summer rainfall region and the Upper Breede catchment with winter frontal rainfall, the confidence in the model's ability to represent hydrological responses under a range of climates has increased. Thus, in effect by using a space for time study, the uncertainty of the model's
Table 8. Statistics of performance of the $A C R U$ model Upper Breede Catchment: comparison of Daily Observed and Simulated Values.

\begin{tabular}{lrr}
\hline WMU (1987-1999) & Koekedou & Upper Breë \\
\hline Total observed flows (mm) & 4209.394 & 1663.064 \\
Total simulated flows (mm) & 4496.732 & 1642.908 \\
Ave. error in flow (mm/day) & 0.070 & -0.005 \\
Mean observed flows (mm/day) & 1.021 & 0.376 \\
Mean simulated flows (mm/day) & 1.091 & 0.372 \\
\% Difference between means & $-6.83 \%$ & $-1.21 \%$ \\
Std. Deviation of observed flows (mm) & 5.323 & 0.812 \\
Std. Deviation of simulated flows (mm) & 5.639 & 0.768 \\
\% Difference between Std. Deviations & $-5.94 \%$ & $5.39 \%$ \\
Correlation Coefficient: Pearson's R & 0.929 & 0.844 \\
Regression Coefficient (slope) & 0.956 & 0.798 \\
Regression Intercept & 0.114 & 0.071 \\
Coefficient of Determination: $R^{2}$ & 0.864 & 0.712 \\
Nash-Sutcliffe Efficiency Index $\left(E_{\mathrm{f}}\right)$ & 0.785 & 0.516 \\
\hline
\end{tabular}

ability to cope with the projected future climate scenarios is reduced. Furthermore, as the model was shown to be sensitive to diverse land uses, including commercial forestry, natural vegetation, urban areas and subsistence agriculture, uncertainties regarding the model's ability to be sensitive to land use change are also seen to be constrained. However, it is noted that the representation of informal residential areas could be a shortcoming of the model, as the unstructured nature of these areas is difficult to capture with the model's input variables. An advantage of the ACRU model over many others, in regard to land use and climate change studies, is that it explicitly simulates the stormflow and baseflow components of streamflow, and this is important as the partitioning of rainfall into different flow components may change under future climatic conditions. Through this confirmation study, the model's ability to represent high flows and low flows was assessed. Although either the low flows or high flows in some WMUs (for example the Lions River WMU) were either slightly over- or undersimulated, overall the representation of low flows and high flows was considered to be good.

\section{Conclusions}

The ACRU model has successfully accounted for a diverse range of land uses within the three catchments used in this study, which provides confidence in the model's ability to assess hydrological responses of land use change. Furthermore, the three catchments selected for the study experience diverse climates, and based on the results produced, the ACRU model performs satisfactorily across the range of climates. It is, therefore, suggested that the model is appropriate as a tool to assess hydrological responses of catchments to land use and climate changes. 
Acknowledgements. The authors would like to thank the Water Research Commission and National Research Foundation for providing the funding for this project.

Edited by: E. Toth

\section{References}

Bewket, W. and Sterk, G.: Dynamics in land cover and its effect on streamflow in the Chemaga watershed, Blue Nile basin, Ethiopia, Hydrol. Process., 19, 445-458, 2005.

Beven, K.: On undermining the science?, Hydrol. Process., 20, 3141-3146, 2006.

Bezuidenhout, C. N.: Development and Evaluation of Model-Based Operational Yield Forecasts in the South African Sugar Industry, Ph.D. thesis, School of Bioresources Engineering and Environmental Hydrology, University of KwaZulu-Natal, South Africa, 137 pp., 2005.

Bronstert, A., Niehoff, D., and Bürger, G.: Effects of climate and land-use change on storm runoff generation: Present knowledge and modelling capabilities, Hydrol. Process., 16, 509-529, 2002.

Butterworth, J. A., Schulze, R. E., Simmonds, L. P., Moriarty, P., and Mugabe, F.: Hydrological processes and water resources management in a dryland environment IV: Long-term groundwater level fluctuations due to variation in rainfall, Hydrol. Earth Syst. Sci., 3, 353-361, doi:10.5194/hess-3-353-1999, 1999.

Calder, I. R.: A model of transpiration and growth of Eucalyptus plantation in water-limited conditions, J. Hydrol., 130, 1-15, 1992.

Calder, I. R.: Blue Revolution II: Land use and integrated water resources management, Earthscan, London, 327 pp., 2005.

Chang, H.: Basin hydrologic response to changes in climate and land use: The Conestoga River Basin, Pennsylvania, Phys. Geogr., 24, 222-247, 2003.

Choi, W. and Deal, B. M.: Assessing hydrological impact of potential land use change through hydrological and land use change modelling for the Kishwaukee River Basin (USA), J. Environ. Manage., 88, 1119-11130, 2008.

Comprehensive Assessment of Water Management in Agriculture: Water for Food, Water for Life: A comprehensive assessment of water management in agriculture, Earthscan and International Water Management Institute, London, 645 pp., 2007.

Costa, M. H., Botta, A., and Cardille, J. A.: Effects of large-scale changes in land cover on the discharge of the Tocantins River, Southeastern Amazonia, J. Hydrol., 283, 206-217, 2003.

Department of Water Affairs and Forestry (DWAF): Breede Water Management Area: Internal Strategic Perspective, South Africa, DWAF Rep. P WMA18/000/00/0304, 2004.

Ewen, J. and Parkin, G.: Validation of catchment models for predicting land-use and climate change impacts, 1 Method, J. Hydrol., 175, 583-594, 1996.

Falkenmark, M., Andersson, L., Castensson, R., Sundblad, K., Batchelor, C., Gardiner, J., Lyle, C., Peters, N., Pettersen, B., Quinn, P., Rockström, J., and Yapijakis, C.: Water: A reflection of land use, Swedish Natural Science Research Council, Sweden, 1999.

Forbes, K. A., Kienzle, S. W., Coburn, C. A., Byrne, J. M., and Rasmussen J.: Simulating the hydrological response to predicted climate change on a watershed in southern Alberta, Canada, Climatic Change, doi:10.1007/s10584-010-9890-x, in press, 2010.

Ghile, Y. B.: An adaptation of the SCS-ACRU hydrograph generating technique for application in Eritrea, MSc dissertation, School of Bioresources Engineering and Environmental Hydrology, University of Natal, South Africa, 2004.

Guo, H., Hu, Q., and Jiang, T.: Annual and seasonal streamflow responses to climate and landcover changes in the Poyang Lake Basin, China, J. Hydrol., 355, 106-122, 2008.

Gush, M. B., Scott, D. F., Jewitt, G. P. W, Schulze, R. E., Lumsden, T. G., Hallowes, L. A., and Görgens, A. H. M.: Estimation of streamflow reductions resulting from commercial afforestation in South Africa, Water Research Commission, South Africa, Rep. TT173/02, 2002.

Hargreaves, G. H. and Samani, Z. A.: Reference crop evapotranspiration from temperature, T ASAE, 1, 96-99, 1985.

Herron, N., Davis, R., and Jones, R.: The effects of large-scale afforestation and climate change on water allocation in the Macquarie River catchment, NSW, Australia, J. Environ. Manage., 65, 369-381, 2002.

Herpertz, D.: Modellierung der Hydrologischen Prozessdynamik im Einzugsgebiet der Bröl mit dem Agrarhydrologischen Flusseinzugsgebietsmodell ACRU, MSc dissertation, Bonn University, Germany, 1994.

Herpertz, D.: Schneehydrologische Modellierung im Mittelgebirgsraum, PhD thesis, Bonn University, Germany, 2001.

Hu, Q., Willson, G. D., Chen, X., and Akyuz, A.: Effects of climate and landcover change on stream discharge in the Ozark Highlands, USA, Environ. Model. Assess., 10, 9-19, 2005.

Jewitt, G. P. W. and Schulze, R. E.: Verification of the $A C R U$ model for forest hydrology applications, Water SA, 25, 483-489, 1999.

Jewitt, G. P. W., Garratt, J. A., Calder, I. R., and Fuller, L.: Water resources planning and modelling tools for the assessment of land use change in the Luvuvhu Catchment, South Africa, Phys. Chem. Earth, 29, 1233-1241, 2004.

Kienzle, S. W., Lorentz, S. A., and Schulze, R. E.: Hydrology and water quality of the Mgeni Catchment, Water Research Commission, South Africa, Rep. TT87/97, 1997.

Kienzle, S. W. and Schulze, R. E.: Simulating daily streamflows in the Mgeni Catchment under past, present and future land uses, in: Proceedings of the 7th South African Hydrology Symposium, Grahamstown, South Africa, 1995.

Kienzle, S. W. and Schmidt, J.: Hydrological impacts of irrigated agriculture in the Manuherikia Catchment, Otago, New Zealand, J. Hydrol. (NZ), 47, 67-83, 2008.

Kiker, G. A., Clark, D. J., Martinez, C. J., and Schulze, R. E.: A Java-based, object-oriented modeling system for southern African hydrology, T ASABE, 49, 1419-1433, 2006.

Legasse, D., Vallet-Coulomb, C., and Gasse, F.: Hydrological response of a catchment to climate and land use changes in Tropical Africa: case study South Central Ethiopia, J. Hydrol., 275, 67-85, 2003.

Lin, Y.-P., Hong, N.-M., Wu, P.-J., and Lin, C.-J.: Modelling and assessing land-use and hydrological processes to future land-use and climate change scenarios in watershed land-use planning, Environ. Geol., 53, 623-634, 2007.

Lumsden, T. G., Jewitt, G. P. W., and Schulze, R. E.: Modelling the impacts of land cover and land management practices on runoff responses, Water Research Commission, South Africa, 
Rep. 1015/1/03, 2003.

Lynch, S. D.: The Development of a Raster Database of Annual, Monthly and Daily Rainfall for Southern Africa, Water Research Commission, South Africa, Rep. 1156/1/04, 2004.

Makoni, S. T.: The sustainable development of water resources in southern Africa, Ph.D. thesis, Technical University of Denmark, Denmark, 2001.

Martinez, C. J., Campbell, K. L., Annable, M. D., and Kiker, G. A.: An object-oriented hydrologic model for humid, shallow watertable environments, J. Hydrol., 351, 368-381, 2008.

Nash J. E. and Sutcliffe, J. V.: River flow forecasting through conceptual models, part I - A discussion of principles, J. Hydrol., 10, 282-290, 1970.

National Land Cover (NLC): Produced by CSIR and ARC consortium, South Africa, 2000.

New, M. G. and Schulze, R. E.: Hydrologic sensitivity to climate change and some implications for erosion in the Langrivier catchment, Western Cape, South Africa, Z. Geomorphol., 107, 11-34, 1996.

Nordstrom, K. M., Gupta, V. K., and Chase, T. N.: Role of the hydrological cycle in regulating the planetary climate system of a simple nonlinear dynamical model, Nonlinear Proc. Geoph., 12, 741-753, 2005.

Oreskes, N., Shrader-Frechette, K., and Belitz, K.: Verification, validation, and confirmation of numerical models in the Earth Sciences, Science, 263, 641-646, 1994.

Perks, L. A.: Refinement of Modelling Tools to Assess Potential Agrohydrological Impacts of Climate Change in Southern Africa, Ph.D thesis, School of Bioresources Engineering and Environmental Hydrology, University of Natal, South Africa, 463 pp., 2001.

Perks, L. A. and Schulze, R. E.: Modelling the potential impacts of climate change on water resources in southern Africa, in: Proceedings of the 9th South African National Hydrology Symposium, Cape Town, South Africa, 1999.

Pfister, L., Kwadijk, J., Musy, A., Bronstert, A., and Hoffman, L.: Climate change, land use change and runoff predictions in the Rhine-Meuse Basins, River Res. Appl., 20, 229-241, 2004.

Quilbé, R., Rousseau, A. N., Moquet, J.-S., Savary, S., Ricard, S., and Garbouj, M. S.: Hydrological responses of a watershed to historical land use evolution and future land use scenarios under climate change conditions, Hydrol. Earth Syst. Sci., 12, 101-110, doi:10.5194/hess-12-101-2008, 2008.

Refsgaard, J. C. and Henriksen, H. J.: Modelling guidelines - terminology and guiding principles, Adv. Water Resour., 27, 71-82, 2004.

Samaniego, L. and Bárdossy, A.: Simulation of the impacts of land use/cover and climatic changes on the runoff characteristics at the mesoscale, Ecol. Model., 196, 45-61, 2006.

Schmidt, J., Kienzle, S. W., and Srinivasan, M. S.: Estimating increased evapotranspiration losses caused by irrigated agriculture as part of the water balance of the Orari Catchment, Canterbury, New Zealand, J. Hydrol. (NZ), 48, 89-94, 2009.

Schulze, R. E.: Assessment of irrigation water demand and supply by agrohydrological modelling: the Winterton example, Agricultural Engineering in South Africa, 20, 90-112, 1988.

Schulze, R. E.: Hydrology and Agrohydrology: A Text to Accompany the $A C R U$ 3.00 Agrohydrological Modelling System. Water Research Commission, South Africa, 552 pp., 1995.
Schulze, R. E.: South African Atlas of Agrohydrology and Climatology, Water Research Commission, South Africa, 1997.

Schulze, R. E.: Modelling hydrological responses to land use and climate change: asouthern African Perspective, Ambio, 29, 12 22,2000 .

Schulze, R. E.: Determination of baseline land cover variables for applications in addressing land use impacts on hydrological responses in South Africa, in: Schulze, R. E. and Pike, A.: Development and evaluation of an installed hydrological modelling system, Water Research Commission, South Africa, Rep. 1155/1/04, 37-50, 2004.

Schulze, R. E.: Selection of a suitable agrohydrological model for climate change impact studies over southern Africa, in: Schulze, R. E.: Climate Change and Water Resources in Southern Africa: Studies on Scenarios, Impacts, Vulnerabilities and Adaptation, Water Research Commission, South Africa, Rep. 1430/1/05, 95110, 2005.

Schulze, R. E. and George, W. J.: A dynamic process-based userorientated model of forest effects on water yield, Hydrol. Process., 1, 293-307, 1987.

Schulze, R. E. and Tarboton, K. C.: Hydrological responses from urbanized areas, in: Hydrology and Agrohydrology: A Text to Accompany the ACRU 3.00 Agrohydrological Modelling System, edited by: Schulze, R. E., Water Research Commission, South Africa, 552 pp., 1995.

Schulze, R. E. and Maharaj, M.: Development of a Database of Gridded Daily Temperatures for Southern Africa, Water Research Commission, South Africa, Rep. 1156/2/04, 83 pp., 2004.

Schulze, R. E. and Smithers, J. C.: The ACRU modelling system as of 2002: Background, Concepts, Structure, Output, Typical Applications and Operations, in: Modelling as a Tool in Integrated Water Resources Management: Conceptual Issues and Case Study Applications, edited by: Schulze, R. E., Water Research Commission, South Africa, Rep. 749/2/04, 47-83, 2004.

Schulze, R. E., Pike, A., Horan, M., and Hughes, G. O.: Hydrological impacts of land use practices on the Lenjane catchment, School of Bioresources Engineering and Environmental Hydrology, University of KwaZulu-Natal, South Africa, ACRUcons Rep., 19, 36 pp., 1997.

Schulze, R. E., Lorentz, S., Kienzle, S., and Perks, L.: Case Study 3: Modelling the impacts of land use and climate change on hydrological responses in the mixed underdeveloped/developed Mgeni catchment, South Africa, in: Vegetation, Water, Humans and the Climate: A new perspective on an interactive system, edited by: Kabat, P., Claussen, M., Dirmeyer, P. A., Gosh, J. H. C., De Guenni, L. B., Meybeck, M., Pielke Sr, R. A., Vörösmarty, C. J., Hutjes, R. W. A., and Lütkemeier, S., Springer, Germany, 441453, 2004.

Schulze, R. E., Lumsden, T. G., Horan, M. J. C., Warburton, M. L., and Maharaj, M.: An assessment of impacts of climate change on agrohydrological responses over Southern Africa, in: Climate Change and Water Resources in Southern Africa: Studies on Scenarios, Impacts, Vulnerabilities and Adaptation, edited by: Schulze, R. E., Water Research Commission, South Africa, Rep. 1430/1/05, 141-189, 2005.

Schulze, R. E., Maharaj, M., Warburton, M. L., Gers, C. J., Horan, M. J. C., Kunz, R. P., and Clark, D. J.: Electronic data accompanying the South African Atlas of Climatology and Agrohydrology, Water Research Commission, South Africa, Rep. 1489/1/08, 
2008.

Smithers, J. C.: Modelling the Nthabamhlope wetland: Initial results, Agricultural Engineering in South Africa, 23, 440-449, 1991.

Smithers, J. C. and Caldecott, R. E.: Development and verification of hydrograph routing in a daily simulation model, Water SA, 19, 263-267, 1993.

Smithers, J. C., Schulze, R. E., Pike, A., and Jewitt, G. P. W.: A hydrological perspective of the February 2000 floods: A case study in the Sabie River Catchment, Water SA, 27, 325-332, 2001.

Smithers, J. C. and Schulze, R. E.: ACRU Agrohydrological Modelling System: User Manual Version 4.00, School of Bioresources Engineering and Environmental Hydrology, University of KwaZulu-Natal, South Africa, 2004.

Summerton, M. J.: A preliminary assessment of the impact of climate change on the water resources of the Mgeni Catchment, Planning Services, Umgeni Water, South Africa, Rep. 160.8/R001/2008, 2008.
Tarboton, K. C. and Schulze, R. E.: Impacts of increased afforestation and farm dams on water resources of the upper Mgeni catchments, Agricultural Engineering in South Africa, 22, 201-215, 1990.

Tarboton, K. C. and Schulze, R. E.: The ACRU modelling system for large catchment water resources management, in: Hydrology for the Water Management of Large River Basins, edited by: Van de Ven, F. H. M., Gutknecht, D., Loucks, D. P. and Salewicz, K. A., IAHS Publication No. 201, 219-232, 1991.

Tarboton, K. C. and Schulze, R. E.: Distributed hydrological modelling system for the Mgeni Catchment, Water Research Commission, South Africa, Rep. 234/1/92, 1992.

Turner, I. I., B. L., Skole, D., Sanderson, S., Fischer, G., Fresco, L., and Leemans, R.: Land-use and Land-cover Change (LUCC): Science/Research Plan, IGBP Rep. No. 35, Stockholm and Geneva, 132 pp., 1995. 